\author{
Majka Aleksandra Omüller \\ Wydział Filologiczny \\ Uniwersytet w Białymstoku \\ e-mail: majka.omuller@gmail.com \\ ORCID: 0000-0001-8817-6286
}

\title{
Obraz Podlasia w reportażu Jutro spadna gromy
}

Jutro spadna gromy to reportaż Bartosza Jastrzębskiego, Jędrzeja Morawieckiego i Macieja Skawińskiego wydany przez białostocką Fundację Sąsiedzi. Jest on zbiorem opowieści relacjonujących wędrówkę autorów po Podlasiu. Reportażyści próbują zmierzyć się ze zmitologizowanym obrazem tego regionu - aby to zrobić, spotykają się z jego mieszkańcami, wsłuchują się w ich opowieści, odwiedzają miejsca szczególnie ważne dla lokalnych społeczności. Konfrontują się z przypisywanym Podlasiu mistycyzmem, w którym mieszczą się różnego rodzaju praktyki magiczne, czarownicy, szeptuchy czy wiara w kontakt z duchami. Analizują także, jak zmieniało się Podlasie, między innymi Białystok, szukają sposobu opisu dynamiki tych zmian, uchwycenia relacji między tradycją i nowoczesnością. Reportaż wzbogacony został fotografiami wykonanymi przez Macieja Skawińskiego.

Jutro spadna gromy można też potraktować jako zapis jednego z etapów podróży autorów na Wschód, tyle że ten geograficznie bliższy - ich wcześniejsze wędrówki odbywały się na terenie Rosji, Buriacji czy Syberii. Tym razem zdobytą na temat Wschodu wiedzę konfrontują z Podlasiem, co być może doprowadzi do dekonstrukcji ich dotychczasowych wyobrażeń. Warto dodać, że funkcjonowanie stereotypów na temat Wschodu nie jest żadnym novum - mają one swój udział w tworzeniu jego egzotycznego, specyficznego obrazu właściwie "od zarania dziejów”, co znakomicie opisał Edward Said. Znajdziemy je również w myśleniu na temat Podlasia, czego świadomość 
mają autorzy Jutro spadna gromy. Być może właśnie ta presupozycja - uwikłania Podlasia w stereotypowy obraz Wschodu - staje się jednym z powodów, by pokazać podlaską rzeczywistość $\mathrm{z}$ różnych perspektyw.

Refleksje o książce Jutro spadna gromy warto rozpocząć od przyjrzenia się specyficznemu sposobowi pracy, jaki przyjęli jej autorzy: Bartosz Jastrzębski, Jędrzej Morawiecki oraz Maciej Skawiński, czyli, jak sugeruje samo wyliczenie nazwisk - tworzeniu reportażu jako pracy zespołowej. Charakter pracy zbiorowej wydaje się bardziej „warsztatowy": zakłada osiągnięcie porozumienia na wielu płaszczyznach, przypomina budowanie skomplikowanej scenografii, której elementy finalnie muszą ze sobą współgrać. Uzgodnień wymaga choćby stopień ingerencji w relacje bohaterów zawarte w reportażu czy postawa wobec nich, uobecniająca się już na etapie prowadzonych rozmów. Wszystko to musi zostać przemyślane i uwzględniać uwagi współautorów. Przy takim rodzaju pracy szczególnie ważne okazują się konsultacje najdrobniejszych szczegółów, aby końcowy efekt pracy był głosem wszystkich twórców danej publikacji. Inaczej zaś ma się sytuacja z dotychczasowym, tradycyjnym, jednoosobowym reportażem, w którym autor odkrywa się ze swoją osobowością, talentem, kompetencjami warsztatowymi ${ }^{1}$. O atrakcyjności reportażu zespołowego stanowi szybkość i efektywność działania reporterów. Obecnie każdy może relacjonować dowolne wydarzenie $\mathrm{z}$ najodleglejszego zakątka świata, zatem reportaż musi sprostać wymaganiom czytelników, którzy wiedzą coraz więcej i coraz łatwiej mogą sami zdobywać różne informacje. Dlatego tak ważne są te atrybuty autorów, które odróżniają ich od przeciętnego twórcy internetowego bloga poświęconego podróżom.

W Jutro spadna gromy kompetencje oraz wcześniejsze doświadczenie reporterów mają niebywałe znaczenie. Wszyscy trzej debiut w pracy terenowej mają już dawno za sobą - Bartosz Jastrzębski i Jędrzej Morawiecki podczas wypraw na Wschód, między innymi do Rosji, Buriacji, na Syberię (reportaże Krasnojarsk zero ${ }^{2}$, Cztery zachodnie staruchy. Reportaż o duchach i szamanach ${ }^{3}$ ) oraz Maciej Skawiński, który jest autorem licznych publikacji i wystaw oraz laureatem World Press Photo. Wszyscy mają więc za sobą pogłębione i udokumentowane doświadczenie Wschodu, a w jego ramach - specyficznej duchowości (inspiracją do jednej z podróży była chęć przyjrzenia się kulturze i praktykom szamańskim). Wszystko to stanowi ważny

1 B. Szady, Kondycja wspótczesnego polskiego reportażu, „Dziennikarstwo i Media” 2012, t. 3, s. 82, https://tiny.pl/tsw4b [dostęp 04.01.2019].

2 B. Jastrzębski, J. Morawiecki, Krasnojarsk zero, Białystok 2012.

3 B. Jastrzębski, J. Morawiecki, Cztery zachodnie staruchy. Reportaż o duchach i szamanach, Białystok 2014. 
punkt wyjścia dla tekstu poświęconego Podlasiu. Równie istotne jest wykształcenie reporterów - Bartosz Jastrzębski jest doktorem habilitowanym w zakresie kulturoznawstwa, zaś Jędrzej Morawiecki - doktorem filologii słowiańskiej oraz socjologii. Wpływa to na ich warsztat, choćby na sposób, w jaki wprowadzają i interpretują konteksty opowiadanych przez swoich bohaterów historii.

Reportaż Jutro spadna gromy wzbogacony jest rekonstrukcjami, zwykle wynikającymi z opowieści napotkanych osób, lecz równie często napisanymi przez samych autorów - dla usensownienia i uzupełnienia wywodu bohatera tekstu - bogatymi w daty, wydarzenia historyczne, fakty ważne dla miejsc istniejących współcześnie. Przykładami mogą być chociażby historia Romualda Rajsa ps. „Bury” czy patrona szkoły w Narewce - Aleksandra Wołkowyckiego ${ }^{4}$. Dla autorów reportażu ważne jest historyczne umiejscowienie wydarzeń - nie można zrozumieć problemów dręczących lokalną społeczność bez zagłębienia się w ich tło historyczne. Reporterzy starają się pokazać różne bieguny jednej historii, nie zależy im na osądzaniu złych lub dobrych czynów, lecz na pokazaniu dwóch odmiennych narracji na temat poszczególnych postaci, w zależności od punktu widzenia traktowanych jako bohaterów i antybohaterów („Bury” i Wołkowycki). Specyfika Podlasia w ich ujęciu jest polifoniczna - odnajduje jedność i harmonię, czasem - dysonans - właśnie w swojej wielogłosowości. Odmienne narracje mają w tym reportażu równoprawny status - taki zabieg może sugerować, że autorzy chcieli maksymalnie zobiektywizować swoją opowieść i nie wypowiadać własnych sądów.

Współczesny reportaż wzbogacany jest nierzadko wkładkami fotograficznymi, nie inaczej stało się w Jutro spadna gromy. Zamieszczone w książce zdjęcia nie stanowią jedynie dokumentacji fotograficznej podróży, lecz stają się samodzielną opowieścią, którą można czytać niezależnie od narracji tekstowej. Ten stan rzeczy zawdzięczamy koncepcji pracy zbiorowej, przyjętej przez autorów. Postawa Morawieckiego i Jastrzębskiego wobec dokonań kolegi-fotografa wpisuje się też w ogólny trend dowartościowania zdjęć przez reportażystów, którzy zaczęli uważać pracę fotoreporterów za wartościową i równie istotną, co ich własne obserwacje. Na ten problem zwraca uwagę Zygmunt Ziątek, pisząc, że reporterzy nie mogą przechodzić obojętnie obok sukcesów fotografów. Wręcz przeciwnie - fotografia staje się dla nich wyzwaniem do tworzenia tekstów lepszych i wiarygodniejszych, nieustępujących kunsztem zdjęciom ${ }^{5}$. Zmiana ta wydaje się znacząca, fotograf nie jest już je-

4 B. Jastrzębski, J. Morawiecki, M. Skawiński, Jutro spadna gromy, Białystok 2015, s. 49-54.

5 Z. Ziątek, Reportaż - fotografia - nowe kryteria wiarygodności, w: Między sztuka a codziennością: w strone nowej syntezy, red. M. Hopfinger, Z. Ziątek, T. Żukowski, Warszawa 2016, s. 110. 
dynie "prawą ręką" reportera, staje się podmiotem w procesie powstawania reportażu - opowiada historię widzianą własnymi oczami. I ta właśnie opowieść może okazać się w momencie odbioru przez czytelnika narracją samodzielną i równorzędną, która nie spełnia jedynie funkcji ilustracyjnej. Jeżeli nawet przyjmiemy perspektywę, że fotografia ma obrazować tekst, opowiadane wydarzenia, konkretyzować rzeczywistość, to mimo tego pozostaje ona wielowarstwowa i pomnożona w poszczególnych odczytaniach kolejnych odbiorców. O tym, że fotografii nie da się włożyć w konkretne ramy, nadać jej ściśle określonych, trwałych cech i funkcji pisał Roland Barthes w książce Światło obrazu. Uwagi o fotografii z $1980 \mathrm{roku}^{6}$. Barthes jasno określa pozycję fotografii jako jednostkowego i niepowtarzalnego ujęcia rzeczywistości w formie obrazu - poświadczenia tego, co się wydarzyło, niemożliwego do zweryfikowania z aktualną rzeczywistością. Kluczowa jest tu decyzja autora zdjęcia, który uchwycił, a zatem wyselekcjonował z całego spektrum możliwości - jeden konkretny kadr. Ujęcie to nabiera tym samym cech symbolicznych, staje się syntetyczną interpretacją jakiegoś wycinka świata. Podobnie dzieje się w Jutro spadna gromy - zdjęcia tam umieszczone (np. mini-cykl zawierający fotografie okiennic) są przez fotografa wybrane, prezentują tylko fragmenty krajobrazu, i tym samym sugerują czytelnikom jakąś syntezę. Co więcej, przekłada się ona na charakterystykę społeczności wiejskiej na podstawie takich właśnie jednostkowych przykładów. Otwarte pozostaje pytanie, czy są one dziełem przypadku, momentalnego zachwytu autora zdjęcia, którego uwagę przykuł malowniczy detal, czy pogłębionej analizy: przyglądając się podlaskim pejzażom $w$ setkach odsłon fotograf uznał, że właśnie te, a nie inne ujęcia i obrazy są dla nich najbardziej reprezentatywne, najlepiej oddają ich specyfikę. Taka synteza jest możliwa dzięki artystycznym walorom tych fotografii - gra światła, wybór perspektywy, która czyni zdjęcia czymś więcej niż zwyczajną relacją z miejsca wydarzeń. Choć punktem wyjścia w przypadku pracy fotografa zawsze będzie to, co realne, efekt końcowy może (a w przypadku zdjęć najlepszych wręcz powinien) zawierać w sobie poetycki wyraz. Roland Barthes w Świetle obrazu zauważa, że właściwie każda fotografia funkcjonuje w sferze studium, czyli dostarcza nam wiedzy o świecie, konkretnych informacji; interpretuje świat w kategoriach ponadjednostkowych kulturalnych, językowych czy politycznych. Nie każda natomiast ma swoje punctum. Studium przysługuje nawet fotografiom pospolitym, obok których przechodzimy obojętnie i nie zwracamy większej uwagi, zaś punctum przesądza o wyjątkowości zdjęcia. To fragment/moment obrazu, który nas dotyka,

${ }^{6}$ R. Barthes, Światło obrazu. Uwagi o fotografii, przeł. J. Trznadel, Warszawa 1996. 
„żądli”, wywołuje emocje. Warto pamiętać, że doznanie to jest kwestią indywidualną - dla każdego odbiorcy to samo zdjęcie może mieć inne punctum. Próba opisania takimi kategoriami reportażu Jutro spadna gromy najpewniej pozwoliłaby na wyrokowanie na temat jakości zdjęć, ich potencjału wywoływania szczególnych emocji u odbiorców. Niesie to jednak za sobą spore ryzyko błędu, ponieważ sfera punctum w swoim zamyśle jest, jak wspomniałam, indywidualną właściwością. Można zatem jedynie podejrzewać, że jakaś fotografia w przypadku konkretnej grupy osób spotka się z reakcjami wzruszenia, nostalgii lub zamyślenia nad przedstawianym obrazem.

Istotny wydaje się w tym kontekście inny walor cyklu fotografii zamieszczonych w książce, mianowicie ich funkcja metatekstowa: skoro zdjęcie, z założenia maksymalnie przystające do rzeczywistości, tak naprawdę stanowi jej interpretację i przetworzenie, tym bardziej powinniśmy spodziewać się takich zabiegów od reportażu, nawet jeśli autorom przyświeca pragnienie maksymalnego obiektywizmu i zamaskowania własnej obecności w opisywanym świecie. Każde przedstawienie rzeczywistości to przecież nic innego, jak subiektywnie dobrany „kadr”, który jest „Wschodem” przepuszczonym przez autorską soczewkę.

W Jutro spadna gromy fotograficzne mini-cykle oddziałują na czytelnika kolorem, wyborem kadru, miejsca, perspektywą. Sprawiają wrażenie zdjęć, które nieprzypadkowo występują obok siebie - jakby swoją zintensyfikowaną obecnością miały wywołać silniejsze wrażenie. Informacje pod poszczególnymi fotografiami są oszczędne, ograniczają się do nazwy miejsca czy osoby, mówią ani mniej, ani więcej niż potrzeba do ich identyfikacji. Historie bohaterów przedstawione w reportażu możemy czytać dwupoziomowo - osobno, jako sam tekst lub same fotografie bądź wspólnie - jako dwie linie narracyjne, które się na siebie nakładają. Z mini-cykli wyłaniają się tematy, które zainteresowały fotoreportera i których reprezentację można, rzecz jasna, znaleźć również w tekście reportażu. Maciej Skawiński zdecydował się pokazać na swoich fotografiach podlaską wieś i jej życie codzienne, z którym przeplata się/współistnieje sfera sacrum i profanum. Znalazł także osobne miejsce na zdjęcia bohaterów reportażu - utrwalił ich konkretny wizerunek, dzięki któremu czytelnik nie musi opierać się wyłącznie na swoich wyobrażeniach. Skawiński wyodrębnił cykl związany z Białymstokiem - jest to znaczący zabieg, sugerujący odmienność i oddzielenie Białegostoku od podlaskiej wsi. Zdjęcia wykonywane z pozycji pasażera samochodu również zajmują szczególne miejsce, zwłaszcza jeżeli zinterpretujemy je w kontekście tego, że autorzy przyjeżdżają z zewnątrz i są obserwatorami nie do końca im znanej rzeczywistości. Okno pojazdu staje się jeszcze jednym, dodatkowym kadrem, podwojeniem obiektywu aparatu. Może też symbolizować izolację reporte- 
rów. Poruszanie się przez nich samochodem wzbudza również podejrzenia miejscowej ludności, która bardzo łatwo identyfikuje obcych (na podlaskiej wsi normą jest, że mieszkańcy znają nie tylko siebie nawzajem, ale też wiedzą, do kogo należy konkretne auto) i wypiera ich w sferę szczególnego traktowania. Intruzi mogą również budzić zawstydzenie swoją obecnością.

Cykl prezentujący fotografie Białegostoku koresponduje $\mathrm{z}$ rozdziałem Złe nauki. Autorzy reportażu porównują miasto Białystok do czystego niemieckiego miasteczka, które co prawda nie ma typowego rynku, lewicowych grafitti czy imigrantów z Afryki, ale czymś jednak je przypomina - jest bar „Elvis" z hamburgerami, kwatery dla białoruskich robotników i hotel „Turkus" dla elity zza wschodniej granicy. Opis ten uświadamia, że wszystko to jest jedynie przymiarką do bycia miastem "zachodnim". Białystok boryka się zarówno $\mathrm{z}$ wewnętrznymi problemami (m.in. sprawa swastyk ${ }^{7}$ oraz teatru TrzyRzecze ${ }^{8}$, podane jako przykłady aktywności lokalnych nacjonalistów i neofaszystów), jak i z trudnościami pojawiającymi się na gruncie współpracy międzynarodowej. Ze względu na swoje położenie geograficzne - Białystok i Podlasie są, jak to określają autorzy, "oknem wystawowym Europy otwartym na Wschód". Reportażyści zauważają, że taka współpraca, z założenia polifoniczna, może nieść pozytywne skutki, budować pokojową koegzystencję - stymulować rozwój turystyki, handlu oraz wymianę kulturalną między narodami. Pozostaje postawić pytanie, czy Białystok - jako miasto, ale i część Podlasia - wykorzystuje ten potencjał, a przy tym mądrze kreuje swój wizerunek? Fotografie Macieja Skawińskiego zdają się diagnozować ten stan rzeczy - Białystok nie jest tutaj miastem jak z pocztówki czy folderu wycieczkowego, wydaje się raczej przesiąknięty marazmem, nastawiony na tanie, konsumpcyjne przyjemności. Co ciekawe, na przedstawiających go zdjęciach brak mieszkańców, w przeciwieństwie do fotografii wykonanych we wsiach i miasteczkach. Wzmacnia to poczucie jego efemeryczności i pewnej sztuczności, jakby był zaledwie atrapą miasta.

Opowieści bohaterów reportażu są pełne historii z życia codziennego, w których pojawiają się mistyczne doświadczenia czy funkcjonujące nadal wierzenia ludowe. Przyjrzyjmy się choćby postaci Piotra Białobrzeskiego, który na co dzień jest brygadzistą w fabryce „Pronar”, a po pracy oddaje się swojej największej pasji - czytaniu. Poszukuje ksiąg religijnych, a za jedną

7 E. Dłużewska, Walczyli ze swastyka, dostali siedzibę na Żoliborzu, „Gazeta Wyborcza”, 14 kwietnia 2015, http://warszawa.wyborcza.pl/warszawa/1,34862,17749329,Walczyli_ze_swas tyka__dostali_siedzibe_na_Zoliborzu.html [dostęp 26.09.2019].

8 U. Krutul, Teatr TrzyRzecze wynosi się z Białegostoku, „Kurier Poranny”, 13 kwietnia 2015, https://poranny.pl/teatr-trzyrzecze-wynosi-sie-z-bialegostoku/ar/4956159 [dostęp 26.09.2019]. 
z najważniejszych uważa księgę Klucz, która miałaby krążyć po Podlasiu, przekazywana $z$ rodziny do rodziny. Piotr Białobrzeski jest bardzo oddany temu tematowi, intryguje go rzekoma tajemnica świata zapisana $\mathrm{w}$ tej księdze . Nie on jeden zna opowieść na temat Klucza i Sybilli. Spora część wiejskiej społeczności, zwłaszcza osoby starsze, odwołuje się do niej - wierzą, że moc uzdrawiania, jaką posiadają szeptuchy, bierze się właśnie ze znajomości świętej księgi. Bezgraniczne zaufanie wobec nadludzkich sił i nieumiejętność (a może niechęć?) racjonalizacji rzeczywistości miewają negatywne skutki. Mogą na przykład prowadzić do ostracyzmu wobec kogoś, kogo uznano za osobę ze „złym spojrzeniem” czy oskarżono o działanie na czyjąśs szkodę przy użyciu magii. Wzmacniają też hermetyzm danej społeczności. O niezrozumieniu i ciągłym poczuciu bycia człowiekiem z zewnątrz opowiada w reportażu Marta Kurzyniec, która w Krynkach założyła antykwariat. Kobieta nie jest „stąd” i choć lokalna społeczność pozornie traktuje ją jak "swoją", Kurzyniec wciąż otrzymuje sygnały, że funkcjonuje w niej jako "nawałacz". Tak nazywa się ludzi, którzy się tutaj nie urodzili, bez względu na to, jak długo $w$ danym miejscu mieszkają. Okazuje się zresztą, że to kategoria bardzo płynna: „nawałoczą” może okazać się każdy - to, czy się nią jest, czy nie, przechodzi do sfery uznania przez lokalną społeczność. Marta Kurzyniec - choć ma na miejscowym cmentarzu swoją najbliższą rodzinę nadal uważana jest za osobę z zewnątrz, co spotyka się z jej stanowczym protestem. Z relacji bohaterki można wysnuć następujący wniosek: rzeczywistość podlaskiej wsi jest bardzo mocno przesiąknięta magicznością i fatalizmem - wszystkiemu i wszystkim ludzie starają się przypisywać jakąś sprawczość i ponadnaturalny sens. Naiwność i wiara w przesądy zdają się być dla takiej społeczności zarówno zbawieniem, jak i utrapieniem. Elementy sfery sacrum nie są tutaj przywoływane okazjonalnie, lecz mają stałe miejsce w życiu każdej rodziny, wsi, miasteczka. Niemałym zainteresowaniem cieszą się na przykład w tej części Polski usługi szeptuch, można powiedzieć, że Podlasie jest ich swoistym zagłębiem. Pomagają, leczą, odczyniają uroki. Korzystanie z ich porad traktuje się jako coś równie - jeśli nie bardziej oczywistego, jak wizyta u lekarza. Zazwyczaj zostają nimi kobiety, przejmując ten dar od swoich babć czy matek. Ojciec Sławomir, prawosławny mnich, opowiada autorom reportażu o niełatwym współistnieniu Kościoła prawosławnego i praktyk leczniczych szeptuch. Choć oficjalnie działania ludowych uzdrowicielek nie są popierane przez Cerkiew, zdarza się, że w najtrudniejszych przypadkach zwracają się one do księdza z prośbą o obrzędy dla chorego - $\mathrm{i}$ ten im nie odmawia.

9 B. Jastrzębski, J. Morawiecki, M. Skawiński, Jutro spadna gromy, s. 28-30. 
Bohaterowie historii opisanych przez Bartosza Jastrzębskiego i Jędrzeja Morawieckiego otrzymali $\mathrm{w}$ fotograficznym przedstawieniu Skawińskiego konkretne "twarze". Widzimy fotografię Marty Kurzyniec, wykonaną w jej antykwariacie w Krynkach podczas snucia opowieści o magiczności Podlasia i trudach życia na prowincji. Inne zdjęcie przedstawia szeptuchę Hannę Bondaruk na tle domu, ujęcie prawdopodobnie wykonane podczas rozmowy z reporterami (co istotne, wybrane także na okładkę książki). Jeszcze inne pokazuje roześmianego Leona Stremkowskiego, który chwali się medalami otrzymanymi od samego Stalina. Wśród fotografii możemy również odnaleźć postać Janusza Korbela, mieszkającego na skraju Białowieży fotografa, dziennikarza i działacza ekologicznego ${ }^{10}$. Każde ze zdjęć pokazuje portretowaną osobę na tle jej codziennej rzeczywistości, w naturalnym dla niej kontekście.

Wybór bohaterów reportażu, jak wskazują autorzy, był w większości dziełem przypadku. Ktoś im został polecony, innym razem coś ich zainteresowało/zaintrygowało i postanowili spotkać się z osobą, która im to przybliży. Reporterzy niejako dali się prowadzić miejscu i ludziom, których spotykają - ich sposób dobierania bohaterów można porównać do efektu domina czy kuli śnieżnej. Czasem, choć nie zawsze, wybierali tzw. liderów opinii. Autorzy zwracają szczególną uwagę na to, że perspektywa oraz sądy poszczególnych osób są jednymi z wielu. Każdy z bohaterów reportażu stał się też nosicielem jakiejś cechy, którą można umieścić w kategorii „podlaskość". Zbiór tych cech tworzy pewien rodzaj mentalnej i auto/bio/geo/graficznej mapy Podlasia, która rysuje się sama, właśnie poprzez specyficzny i niewymuszony dobór bohaterów. Podlasie widziane oczami tych osób nie może stanowić jedynej prawdy o nim - suma ich opowieści składa się natomiast na jakiś jego, uchwycony $\mathrm{w}$ momencie powstawanie reportażu, obraz ${ }^{11}$.

Interpretując obraz Podlasia, jaki wyłania się z Jutro spadna gromy, warto przyjrzeć się bliżej wizerunkowi Białegostoku, miasta, które, jak już wspominałam, zostało przez reporterów dość ostro przeciwstawione podlaskiej wsi. O tym, jaki współcześnie jest Białystok, dowiadujemy się z relacji księdza Kułakowskiego ${ }^{12}$. Zauważa on coraz mniejsze zainteresowanie ludzi młodych mieszkaniem na wsi, widzi w nich osoby zatroskane o swój byt, goniące

\footnotetext{
10 Janusz Krobel zmarł 7 sierpnia 2015 r. (w roku wydania Jutro spadna gromu) w wieku 69 lat. https://dzikiezycie.pl/archiwum/2015/wrzesien-2015/janusz-korbel [dostęp 06.01.2019].

11 Wywiad przeprowadzony przez Andrzeja Bajguza z autorami Jutro spadna gromy dla Polskiego Radia Białystok. https://www.radio.bialystok.pl/podrozepokulturze/index/id/127 515 [dostęp 04.01.2019].

12 B. Jastrzębski, J. Morawiecki, M. Skawiński, Jutro spadna gromy, s. 19.
} 
za doczesnymi sprawami, które zostały niejako „wciągnięte” przez zurbanizowaną przestrzeń. Miasto przestaje być jednak atrakcyjne $\mathrm{w}$ momencie, kiedy w człowieku pojawia się potrzeba wyciszenia - wtedy to wieś staje się pożądaną alternatywą. Innego zdania jest bohater rozdziału „Szeregowcy różnorodności" - K., który wyprowadził się z Białegostoku do Warszawy i obecnie tworzy profil facebookowy o nazwie "Sztuczne Fiołki" ${ }^{13}$. K. nie jest zdania, że Białystok czy podlaska wieś to złe miejsce do życia - dochodzi jednak do wniosku, że to przestrzeń niewystarczająca dla osoby młodej, chcącej się rozwijać. Podobne doświadczenia - przeprowadzki do większego miasta - mają też inni członkowie jego rodziny, także w poprzednich pokoleniach. Wiąże się $\mathrm{z}$ tym niejako wpisana $\mathrm{w}$ tego typu mobilność tęsknota za pozostawionymi gdzieś biskimi. K. przywołuje głosy znajomych, którzy Podlasie uważają za miejsce, w którym można się "zatrzymać”, doświadczyć slow motion czy "poczuć miłość"14. Bohaterowi marzy się Białystok, który jest bardzo liberalny i elastyczny, jednak zauważa, że takie idee to „utopia piękna i straszna zarazem" ${ }^{15}$, być może zagrażająca tożsamości danego miejsca. Widzi go jako miasto, które jeszcze nie rozpoczęło procesu modernizacji w duchu liberalizmu, otwiera się zatem przed nim perspektywa pogodzenia różnorodności i nowoczesności $\mathrm{z}$ tradycją, o co trudno w stolicy - mieście pełnym ideologii, która żąda, aby ją "łykać bez ustanku"16.

Białystok poznajemy również dzięki wrażeniom samych reporterów. Kiedy wjeżdżają do miasta, okazuje się, że ich oczekiwania wielkomiejskości, pośpiechu czy anonimowości (cechy naturalnie przypisywane miastom) nie zostają spełnione - Białystok po prostu taki nie jest. Jego przestrzeń analizują bez emocji, nie robi na nich wrażenia dworzec PKS, architektura - można odnieść wrażenie, że nie mają w sobie ciekawości, która zwykle towarzyszy odwiedzaniu nowych miejsc. Przyznają się do niezrozumienia tęsknoty niektórych za podlaską prowincją, od samego miasta również nie oczekują zbyt wiele. Z tych opowieści wyłania się Białystok pretendujący do bycia atrakcyjną aglomeracją, która posiada wszystko, co potrzebne do życia - taki obraz Białegostoku widzimy też na fotografiach Macieja Skawińskiego. Choć Białystok prezentuje się jako wystarczająco "przyjazny” dla swoich mieszkańców, to łatwo dostrzec, że w oczach autorów jest miastem bez szczególnych właściwości. W reportażu wspominają swoją "wycieczkę" po białostockich klubach i dyskotekach, kiedy to dali się "ponieść" atmosferze miasta

\footnotetext{
13 https://pl-pl.facebook.com/SztuczneFiolki/ [dostęp 27.04.2019].

14 B. Jastrzębski, J. Morawiecki, M. Skawiński, Jutro spadna gromy, s. 37.

15 Tamże, s. 39.

16 Tamże.
} 
- prawdopodobnie skuszeni chęcią autentycznego "zanurzenia” się w nim. Konwencja, jaką przyjęli w opisie tej sytuacji jest oniryczna - „I wiruje białostocki świat, widmowy, pocięty na plastry. Niewygodne pytania gasną pod naporem postradzieckich hitów. Gubimy azymut, zapominamy o przyczynie wyprawy [...]. Noc zwiastuje klęskę" ${ }^{17}$. Ten fragment ilustruje nieudaną próbę upojenia się atmosferą miasta, wniknięcia w mentalność ludzi tu mieszkających. Reporterzy dochodzą do wniosku, że niewiele przyswoili i pojęli, a ich dotychczasowa podróż okazała się błądzeniem. Mimo że przyznają się do klęski niezrozumienia tego, co dotychczas zobaczyli i czego doznali, świadczy to jedynie o tym, że Białystok, Podlasie, a zwłaszcza miejsca przygraniczne wymagają znacznie więcej czasu na refleksję i poznanie niż jednodniowa wycieczka.

Problem, na który natknęli się autorzy reportażu, nie dotyczy tylko ich. Miasto Białystok w ogólnopolskiej narracji jest kreowane jako czyste i przyjazne do zamieszkania, jednak próżno szukać opisów zachęcających podróżnych do wakacyjnych wycieczek. Białystok nie jest dla turystów celem podróży, lecz jedynie miejscem przesiadkowym na trasie do Białowieży, Supraśla, Tykocina czy bardziej „dzikich” zakątków Podlasia. Trudno się temu dziwić - Białystok to miasto stosunkowo małe ${ }^{18}$, w którym nie ma aż tak wielu zabytków i atrakcji przyciągających turystów, jak w innych, większych aglomeracjach Polski. Wizerunek stolicy województwa podlaskiego w Internecie również nie zachęca turystów do dłuższego pobytu - ktoś, kto szuka informacji na temat możliwości zwiedzania Białegostoku spotka się w sieci z nagłówkami w stylu: „Białystok na weekend” 19, "Białystok - zwiedzanie w 2-3 godziny" 20 czy „Białystok w jeden dzień" ${ }^{21}$. Takie opisy nie skłaniają do pozostawania tu na dłużej, a już na pewno nie sprzyjają myśleniu, że Białystok ma turystom wiele do zaoferowania. Tymczasem - co książka $J u$ tro spadna gromy zdaje się potwierdzać - zbliżenie się do podlaskiego genius loci wymaga poświęcenia znacznie więcej czasu niż weekendowy wypad. Być może też warunkiem zrozumienia specyfiki Podlasia i Białegostoku jest dekonstrukcja stereotypów i mitów z nim związanych, której próbują

\footnotetext{
17 Tamże, s. 21.

18 Wystarczy porównać dane udostępnione przez Główny Urząd Statystyczny - https://stat. gov.pl/statystyka-regionalna/rankingi-statystyczne/miasta-najwieksze-pod-wzgledem-powie rzchni/ [dostęp 29.04.2019].

19 https://madameedith.com/podroze/polska/bialystok-warto-zobaczyc/ [dostęp 07.04.2019].

20 https://bialystoksubiektywnie.com/blog/2016/04/02/atrakcje-bialegostoku-co-warto-zob aczyc/ [dostęp 07.04.2019].

21 https://www.evitravel.pl/2018/12/bialystok-w-jeden-dzien-co-zobaczyc-i-czego-sprobow ac/ [dostęp 07.04.2019].
} 
dokonać Jastrzębski, Morawiecki i Skawiński, co chwila jednak wpadając $\mathrm{w}$ ich metaforyczne i narracyjne sidła. Praca $\mathrm{w}$ terenie, która jest częścią obowiązków reportera, często przysparza kłopotów. Aby zdobyć zaufanie i szczerość spotykanych osób, reporter musi posiadać umiejętność nawiązywania z nimi kontaktu. Ważne jest też, aby był żywo zainteresowany tematem, o którym pisze, i miał jakąś wiedzę z nim związaną - to jedne z warunków pozyskania sympatii interlokutorów. Rozmowę musi rozgrywać tak, by zgromadzić jak najwięcej informacji, a rozmówca nie odniósł wrażenia, że reporter jest tu tylko po to, żeby się czegoś dowiedzieć. Mimo spełnienia tych warunków często zdarza się, że pytający nie jest $\mathrm{w}$ stanie wydobyć informacji, na których mu zależy. $Z$ podobnym problemem spotkali się autorzy Jutro spadna gromy, kiedy odwiedzili ojca Gabriela, prawosławnego mnicha, w jego skicie w Odrynkach. Ojciec przeprowadził z nimi bardzo rzeczową i konkretną rozmowę. Przedstawił się jako gospodarz pustelni i opowiedział historię tego miejsca. Punkt zwrotny nastąpił w momencie, kiedy reporterzy, bazując na swojej rozległej wiedzy, w spontaniczny sposób zaprzeczyli, jakoby świątynia w skicie mogła być wzorowana na tej z przełomu XIII i XIV wieku z Syberii Zachodniej. Ojciec Gabriel zareagował stanowczo i przerwał spotkanie ${ }^{22}$. Spontaniczna chęć stanięcia po stronie prawdy historycznej kosztem „prawdy reportażu” doprowadziła do dość gwałtownego zakończenia rozmowy - reporterzy zostali potraktowani jak niechciani goście.

Odwiedziny w skicie stały się okazją do konfrontacji dotychczasowych wyobrażeń autorów o duchowości, walorach metafizycznych i otwartości Wschodu, w których nie ma miejsca na małostkowość, próżność czy nadmiernie rozwiniętą miłość własną, z rzeczywistością. Rozmowa doprowadziła do zdemaskowania pewnego mitu, który - co więcej - w jakiś sposób funduje społeczność zgromadzoną wokół ojca Gabriela ${ }^{23}$ : skit w Odrynkach stworzony przez zakonnika jest miejscem, gdzie wierni realizują swoje duchowe potrzeby czy też przyjeżdżają kierowani ciekawością i przyciągani sławą sanktuarium.

\footnotetext{
22 B. Jastrzębski, J. Morawiecki, M. Skawiński, Jutro spadna gromy, s. 67-73.

23 O radykalnych poglądach ojca Gabriela i jego kontrowersyjnych wypowiedziach, np. na temat uchodźców i kultury Zachodu pisała Ewa Zwierzyńska. Zob. E. Zwierzyńska, „Święta Ruś” na bagnach, "Czasopis” 2017, nr 4, s. 19-23: „Poglądy ojca Gabriela są surowe i grubo ciosane, podobnie jak bale, z których wybudował na bagnach swoją cerkiewkę. Gdyby wypowiedział je jakiś zwykły, niewykształcony zjadacz chleba na ulicy - można by je skwitować wzruszeniem ramion, gdy wypowiada je kapłan, który naucza swoje owieczki - wzbudzają niepokój, a gdy mówi je archimandryta, którego pustelnia wyrasta na drugi - obok Grabarki - ośrodek promieniowania prawosławia na Podlasiu - wymagają reakcji".
} 
Opisana wyżej sytuacja stanowiła wyjątek $-\mathrm{z}$ reguły reporterzy byli przyjmowani przez ludzi życzliwie, wzbudzali raczej zaciekawienie niż wrogość. Nie starali się też uchodzić za autochtonów. Na zdjęciach Macieja Skawińskiego widać, że autorzy książki nie unikają przedstawiania siebie jako przyjezdnych, a nawet czynią z tego jeden $\mathrm{z}$ ważnych elementów narracji. Bardzo wymowne jest pod tym względem zdjęcie wykonane właśnie w Odrynkach: Jastrzębski i Morawiecki stoją na nim tyłem do fotografa, ubrani w wygodne do wędrówki stroje, z plecakiem i torbą na ramieniu. Przed nimi biegnie kładka prowadząca do skitu, której koniec ginie na linii horyzontu. Reporterzy zdają się zapraszać nas, odbiorców do wspólnej wędrówki w nieznane, ale też nie kryją, że będziemy patrzeć na podlaski świat ich oczami. Przyjęcie zewnętrznej wobec poznawanej rzeczywistości perspektywy, wyraz pewnego dystansu sygnalizują też fotografie zrobione $\mathrm{z}$ okna samochodu. Takie ujęcia prawdopodobnie stanowią sugestię, że reporterzy nie chcą się wcielać w tkankę Podlasia, tylko przedstawić ją najwiarygodniej, jak potrafią, nie uzurpując sobie prawa do posiadania jej na wyłączność, stania się jej częścią, objęcia całego jej spectrum.

Na osobną uwagę zasługuje motyw okna, kluczowy element pierwszego mini-cyklu zdjęć Macieja Skawińskiego. Czarno-białe fotografie, przedstawiające w centralnym miejscu okiennice, przywołują skojarzenia z otwartością, gościnnością, brakiem barier. Należy wspomnieć, że część Podlasia położona między Trześcianką, Socami i Puchłami nazywana jest „Krainą Otwartych Okiennic", ze względu na udział w projekcie mającym na celu zachowanie krajobrazu kulturowego tych terenów ${ }^{24}$. Umieszczenie przez Skawińskiego cyklu z okiennicami jako pierwszego wydaje się w tym kontekście znaczące. Być może autorzy spotkali się z takim określeniem już wcześniej, zanim tutaj przyjechali, lub stylistyka podlaskich domów na wsiach urzekła ich na tyle, że chcieli to zamanifestować.

O znaczeniu okna w kulturze pisała Ewa Rewers w książce Post-polis ${ }^{25}$. Jej interpretacja okaże się szczególnie ważna, jeżeli spojrzymy na okno jako element dwóch przestrzeni - wiejskiej i miejskiej. Autorka zwraca uwagę na to, że okno jest pewnego rodzaju medium, pasem łączącym świat wewnętrzny z zewnętrznym. To element domu, który umożliwia spotkanie jego wnętrza ze społecznością będącą na zewnątrz. Okno ma jeszcze jedną ważną funkcję: jest filtrem przepuszczającym rzeczywistość - przez nie ogląda się świat, lecz zawsze w wyniku pewnej selekcji obrazów. Wszystkie okiennice,

24 http://www.ciekawepodlasie.pl/szlaki_podlasia/3,Kraina_otwartych_okiennic.html [dostęp 12.01.2019].

25 E. Rewers, Post-polis: wstęp do filozofii ponowoczesnego miasta, Kraków 2007. 
zarówno w przestrzeni miejskiej, jak i wiejskiej, są przedłużeniem ludzkiego oka, lecz w mieście mają szczególną właściwość - przez okno bloku mieszkalnego czy kamienicy można wyjrzeć, ale zajrzeć do niego jest już o wiele trudniej ${ }^{26}$. Uniemożliwia to wysokość budynków czy chęć izolowania się ludzi od świata zewnętrznego, nazywana dbaniem o własną prywatność. To metaforyczne „zawieszenie” między niebem a ulicą. Fotografie okiennic w Jutro spadna gromy ilustrują tę kwestię nieco inaczej - wiejskie okiennice to rodzaj ekspozycji, uzewnętrzniania się domowników, są przyozdobione firankami, kwiatami. Trudno dojrzeć w nich cokolwiek więcej za dnia, ale wieczorem, gdy zapalają się sztuczne światła, okno staje się „widokiem na życie mieszkańców”. Przed potencjalnym "podglądaczem” otwiera się perspektywa spektaklu - okiennic będących miejscem dla widowni, która spogląda na wydarzenia oświetlane wewnątrz domu.

W umieszczeniu zdjęć okiennic na początku książki można doszukiwać się również pewnej formy samoidentyfikacji reporterów. Może to być odautorski, metaforyczny komentarz mówiący o tym, że ich „oknem na świat" są przywiezione na Podlasie stereotypy i kompetencje, które będą już na miejscu poddawane weryfikacji (w pierwszym przypadku) i wykorzystywane (w drugim). Reporterzy występują tutaj w roli pielgrzymów, którzy zaglądają $\mathrm{w}$ nowe miejsca i zadają elementarne pytania, aby przekonać się, czy cel ich podróży został osiągnięty ${ }^{27}$. Przypomnijmy, że każdy z nich doświadczył już wcześniej wschodniości, wyobrażanej między innymi jako gościnność czy szczególna wrażliwość na sferę duchową człowieka. Otwarte okiennice byłyby też wyrazem odczuwanej na początku podróży nadziei, że do „istoty" Podlasia, tak, jak do wnętrza domu, można będzie zajrzeć. Później (o czym już pisałam) okna domów zamienią się w okna samochodu, sygnalizując zwiększenie dystansu między reporterami a eksplorowanym przez nich światem.

Reportaż Jutro spadna gromy to próba zmierzenia się z tym, co o Podlasiu powszechnie wiadomo, ale co nadal funkcjonuje $\mathrm{w}$ sferze mitu i potrzebuje dekonstrukcji. Autorzy zechcieli podjąć takie wyzwanie i sprawdzić, czym jest „podlaska dusza”, jak toczy się życie na pograniczu oraz jak wschodni mistycyzm czy "metafizyka prowincji” 28 wyglądają w praktyce. W efekcie powstała autorska, subiektywna "mapa Podlasia”, na której osobiste doświadczenia reporterów sąsiadują ze stereotypowymi wyobrażeniami na temat tego regionu, tworząc oświetlające się nawzajem, "sensotwórcze”

\footnotetext{
26 Tamże, s. 64.

27 Tamże.

28 Tytuł książki Jana Kamińskiego z 2000 roku.
} 
punkty. Zaznaczają się na niej wyraźnie różne, często spolaryzowane, sfery i cechy. Próba napisania syntezy dotyczącej sporego obszaru geograficznego i tak różnorodnej mozaiki społecznej (od podlaskich chłopów, przez prawosławnego mnicha po pisarza i animatorów kultury) zawsze będzie wiązać się z ryzykiem uogólnienia, pominięcia pewnych wątków, a z drugiej strony - reportersko-badawczej subiektywizacji. Badawczej, bo przecież, jak sygnalizowałam na początku, autorzy książki są też naukowcami, co z pewnością wpłynęło nie tylko na interpretację, ale też selekcję opisywanych przez nich osób i zdarzeń.

Mapa Podlasia, która wyłania się z reportażu, jeszcze lepiej spełni swoją funkcję, jeżeli dokona się próby stworzenia czegoś na kształt legendy do niej. Jej poszczególne elementy nazwałabym następująco: sacrum i profanum, nowoczesność i archaiczność, „białostockość” i „podlaskość”. Sacrum i profanum to kategorie, bez których trudno byłoby opisać podlaską czy wschodnią tożsamość - choć są one swoimi przeciwieństwami, funkcjonują w ścisłej korelacji, warunkując się nawzajem. Podlasie autorów Jutro spadna gromy to świat, w którym krzyże i kapliczki przydrożne spotykają się z reklamami barów szybkiej obsługi, ludzie wiary katolickiej i prawosławnej zawierają małżeństwa, korzystanie z pomocy medycznej nie wyklucza zaczerpnięcia porady $\mathrm{u}$ szeptuchy, a racjonalne myślenie splata się $\mathrm{z}$ wszechobecnym fatalizmem i poczuciem nieuchronności przeznaczenia.

Podlasie to także spotkanie nowoczesności z archaicznością, nie tylko na poziomie architektury, co ilustrują zdjęcia Skawińskiego. Jest to nieustanne ścieranie się żywiołu wiedzy z myśleniem intuicyjnym, naznaczonym często doświadczeniami przekazywanymi z pokolenia na pokolenie. W podlaskich wsiach często żyją całe rodziny, które nigdy nie zmieniły miejsca zamieszkania, mocno związane z lokalną tradycją. Współcześnie, o czym piszą także autorzy reportażu, Podlasie boryka się z migracją młodych ludzi do większych miast, które oferują im pracę, a co za tym idzie lepsze warunki życia. Proces ten trwa niemal nieprzerwanie od lat 50. XX wieku - pisał o tym podlaski Białorusin Sokrat Janowicz, między innymi w opowiadaniu Wielkie miasto Białystok ${ }^{29}$. Jego bohater włóczy się po ulicach miasta, co krok spotykając swoich znajomych pochodzących ze wsi, którzy zaznawszy wielkomiejskiego życia, nie myślą wcale o powrocie w rodzinne strony. Autorzy spotykają się z Podlasiem, które swoją cudowność i magiczność rozpoznaje głównie we wspomnieniach starszych mieszkańców. To miejsce, gdzie dbałość o tradycyjne budownictwo wynika raczej z potrzeby zachowania tego,

29 S. Janowicz, Wielkie miasto Białystok, Warszawa 1973. 
co z niego pozostało (wspomniana „Kraina Otwartych Okiennic"), niż z dążenia do twórczego kultywowania tradycji przodków, na przykład w projektach nowych domów.

Wszystkie te refleksje i spostrzeżenia, czasem artykułowane wprost, a czasem jedynie sugerowane, np. zestawieniem zdjęć drewnianych domów $\mathrm{z}$ dość nijaką architekturą Białegostoku, znajdziemy w Jutro spadna gromy. Autorzy przyjmują rolę medium, przez które mówią bohaterowie książki, projektujący opowieść o swojej „małej ojczyźnie”. Czy przedstawione w ten sposób Podlasie jest bramą na Wschód? A może podlaskość to tylko pewna projekcja, ściśle zależna od perspektywy i intencji tego, kto ją wywołuje? Jedno wydaje się pewne: ten reportaż to kolejna próba ocalenia świata, którego za kilkanaście lat może już nie być - świata szeptuch, tajemniczych ksiąg, drewnianych chat i ciągnących się po horyzont krajobrazów.

\section{Bibliografia}

Barthes Roland (1996), światło obrazu. Uwagi o fotografii, przeł. J. Trznadel, Warszawa: Wydawnictwo KR.

Dłużewska Emilia (2015), Walczyli ze swastyka, dostali siedzibę na Żoliborzu, „Gazeta Wyborcza", 14 kwietnia, http://warszawa.wyborcza.pl/warszawa/1,34862,1774 9329,Walczyli_ze_swastyka__dostali_siedzibe_na_Zoliborzu.html.

Krutul Urszula (2015), Teatr TrzyRzecze wynosi się z Białegostoku, „Kurier Poranny”, 13 kwietnia, https://poranny.pl/teatr-trzyrzecze-wynosi-sie-z-bialegostoku/ar/ 4956159.

Janowicz Sokrat (1973), Wielkie miasto Białystok, przeł. M.J. Konowicz i in., Warszawa: Wydawnictwo Iskry.

Jastrzębski Bartosz, Morawiecki Jędrzej, Skawiński Maciej (2015), Jutro spadnq gromy, Białystok: Fundacja Sąsiedzi.

Rewers Ewa (2007), Post-polis: wstęp do filozofii ponowoczesnego miasta, Kraków: Universitas.

Szady Beata (2012), Kondycja wspótczesnego polskiego reportażu, „Dziennikarstwo i Media", t. 3, s. 75-85.

Ziątek Zygmunt (2016), Reportaż - fotografia - nowe kryteria wiarygodności, w: Między sztuka a codziennością: w stronę nowej syntezy, red. M. Hopfinger, Z. Ziątek, T. Żukowski, Warszawa: Wydawnictwo IBL PAN, s. 83-133.

Zwierzyńska Ewa (2017), „Święta Ruś" na bagnach, „Czasopis”, nr 4, s. 19-23.

https://dzikiezycie.pl/archiwum/2015/wrzesien-2015/janusz-korbel

https://www.radio.bialystok.pl/podrozepokulturze/index/id/127515

https://pl-pl.facebook.com/SztuczneFiolki/

https://stat.gov.pl/statystyka-regionalna/rankingi-statystyczne/miasta-najwieksze-

pod-wzgledem-powierzchni/ 
https://madameedith.com/podroze/polska/bialystok-warto-zobaczyc/ https://bialystoksubiektywnie.com/blog/2016/04/02/atrakcje-bialegostoku-cowarto-zobaczyc/

https://www.evitravel.pl/2018/12/bialystok-w-jeden-dzien-co-zobaczyc-i-czegosprobowac/

http://www.ciekawepodlasie.pl/szlaki_podlasia/3,Kraina_otwartych_okiennic.html https://biezenstwo.pl/fakty/

https://www.sfp.org.pl/baza_wiedzy,307,19473,1,1,Podlaski-Polski-czar.html

\title{
Pictures of Podlasie in the Literary Reportage
}

Jutro spadna gromy

\begin{abstract}
The article analyzes the depiction of Podlasie in the literary reportage Jutro spadna gromy by Bartosz Jastrzębski, Jędrzej Morawiecki and Maciej Skawiński. The author concentrates on the authorial voice and the professional background of the writers, emphasizing in particular the photographic narrative of the place created by Maciej Skawiński. The article also discusses the image of Podlasie and its capital city - Białystok.
\end{abstract}

Keywords: literary non-fiction, reportage, borderland, Białystok, East 